\title{
HUBUNGAN EKSPRESI NEGATIF MLH-1 DENGAN GAMBARAN KLINIKOPATOLOGIK KARSINOMA KOLOREKTAL
}

\author{
Selly Alinta Syukri ${ }^{1}$ Tofrizal $^{2}$, Aswiyanti Asri ${ }^{2}$, Salmiah Agus $^{2}$
}

\begin{abstract}
Abstrak
Instabilitas mikrosatelit (IM) merupakan jalur karsinogenesis Karsinoma Kolorektal (KKR), ditandai dengan delesi atau insersi nukleotida karena defek pada gen perbaikan ketidak cocokan DNA. Karsinoma kolorektal yang terjadi melalui jalur IM memberikan prognosis lebih baik dan respon adjuvan kemoterapi berbeda dari KKR jalur lain. Permasalahan pada gen MLH-1 seringkali terkait dengan parameter klinikopatologik (usia, jenis kelamin, lokasi tumor dan subtipe histopatologik). Gambaran klinikopatologik dengan ekspresi MLH-1 meningkatkan ketepatan terapi. Tujuan penelitian ini adalah menentukan hubungan ekspresi negatif MLH-1 dengan gambaran klinikopatologik KKR. Penelitian ini merupakan studi potong lintang dengan melibatkan 50 kasus KKR yang didiagnosis di empat laboratorium Patologi Anatomik Sumatera Barat. Sampel diambil dari blok paraffin jaringan pembedahan, diklasifikasikan berdasarkan usia, jenis kelamin, lokasi tumor dan subtipe histopatologik. Antibodi MLH-1 diproduksi oleh D Bio System (DBS). Pewarnaan dilakukan untuk menentukan ada/ tidaknya ekpresi MLH-1 pada inti sel tumor. Analisis statistik bivariat menggunakan uji Chi-square, T-Test dan One Way Annova dengan nilai $p<0,05$ dianggap signifikan. Hasil penelitian menunjukkan ekspresi negatif MLH-1 ditemukan pada 17 kasus (34\%). Analisis statistik menunjukkan hubungan tidak bermakna antara ekspresi negatif MLH-1 dengan usia, jenis kelamin, lokasi tumor (nilai $p$ berturut-turut $0,277,0,557$ dan 0,093$)$ dan hubungan bermakna dengan subtipe histopatologik $(p=0,002)$. Simpulan adalah ekspresi negatif MLH-1 meningkat pada pasien KKR berusia $>40$ tahun, jenis kelamin laki-laki, lokasi tumor di proksimal dan subtipe histopatologik karsinoma musinosa.
\end{abstract}

Kata kunci: karsinoma kolorektal, MLH-1, gambaran klinikopatologik

\begin{abstract}
Microsatellite instability (MI) is carcinogenesis pathway of Colorectal carcinoma (CRC). CRC that was characterized by deletions or insertions within nucleotide due to defects in DNA mismatch repair gene. Microsatellite instability gives better prognosis and different chemotherapy adjuvant respons from others. The problem of MLH-1 gene often associated with clinicopathologic features (age, sex, tumor location and histopatologic subtype) and it can increase the succesfull of therapy. The objective of this study was to determine the correlation of negative expression of MLH-1 and clinicopathological features. This was a cross sectional study in Padang with fifty cases which had been diagnosed in four Pathology Anatomy Laboratory in West Sumatera. Samples were obtained from parafin block of tissue surgery and have been classified into age, sex, tumor location and histopathological subtype. Staining were done to find presence/ absence of MLH-1 expression in tumor cell nuclei. Chi square-test, T-test and One Way Annova bivariate statistical analysis were used with $p$ value $<0.05$ were considered significant. The results is negative expression of $\mathrm{MLH}-1$ was found in seventeen cases (34\%). Statistical analysis showed unsignificant correlation between negative expression of $M L H-1$ with age, sex, tumour location ( $p$ value subsequently 0,277, 0,557 and 0,093) and significant with histopathologic subtype $(p=0,002)$. The conclusion is $M L H$-1negative expression was mostly found in the age of $>40$ years old, male, proximal location and mucinous subtype.
\end{abstract}

Keyword: colorectal carcinoma, $M L H-1$, clinicopathologic features 
Affiliasi penulis: 1 Rumah Sakit Umum M. Zein, Painan, Pesisir Selatan Sumatera Barat, 2. Bagian Patologi Anatomi Fakultas Kedoteran Unand Padang.

Korespondensi: pat anatomik@fk.unand.ac.id Telp: (0752) 21176

\section{PENDAHULUAN}

Karsinoma kolorektal adalah tumor ganas berasal dari epitel yang melapisi mukosa dan kripti kolorektal. ${ }^{1}$ Karsinoma kolorektal invasif didefinisikan sebagai infiltrasi sel tumor ganas melalui tunika muskularis mukosa ke submukosa dan/ atau jaringan lunak yang lebih dalam.Lebih dari $90 \%$ KKR adalah adenokarsinoma konvensional meskipun terdapat beberapa subtipe histopatologik jarang lainnya. ${ }^{1}$

Kejadian karsinoma kolorektal (KKR) terus meningkat dari tahun ke tahun, baik di dunia maupun di Indonesia. Angka kejadian KKR di dunia, menempati urutan ketiga terbanyak pada laki-laki dan kedua terbanyak pada perempuan. ${ }^{2}$ Insidens laki-laki menderita KKR diperkirakan 25\% lebih tinggi jika dibandingkan dengan perempuan dan lebih dari $90 \%$ kasus KKR terjadi pada laki-laki dan perempuan yang berusia diatas 50 tahun. $^{3} \mathrm{Di}$ negara maju, angka kejadian KKR lebih tinggi dibandingkan dengan negara berkembang, yaitu sebanyak $55 \%$. $^{2} \mathrm{Di}$ Indonesia, KKR menjadi kasus keganasan ketiga terbanyak setelah karsinoma payudara dan karsinoma paru serta penyebab kematian ketiga akibat kanker pada laki-laki dan penyebab kematian keempat akibat kanker pada perempuan. Di Sentra Diagnostik Patologi Anatomik (SDPA) Fakultas Kedokteran Universitas Andalas periode Januari 2009 sampai Desember 2011 didapatkan kasus KKR sebanyak 260 kasus, dengan perbandingan laki-laki : perempuan adalah $1: 1,18{ }^{4}$

Secara global angka mortalitas akibat KKR ini terus meningkat dan angka kelangsungan hidup akibat penyakit ini cenderung menurun, terutama di negara berkembang. ${ }^{3}$ Hal ini disebabkan karena beberapa hal, diantaranya penyakit ini umumnya didiagnosis pada stadium lanjut dan KKR merupakan penyakit heterogen yang memiliki gambaran klinik serta subtipe histopatologik yang berbeda-beda sehingga prognosis dan respon terapi individual juga berbeda-beda, meskipun berada pada stadium patologik yang sama. ${ }^{5}$
Tingginya beban penyakit kanker kolorektal di Indonesia menyebabkan terus dikembangkannya penelitian-penelitian untuk memahami karakteristik penyakit, dengan tujuan untuk memperbaiki manajemen yang sesuai dengan karakteristik kejadian KKR di Indonesia.

Faktor risiko KKR seperti pola diet, riwayat keluarga dengan KKR atau polip adenomatosa dan riwayat penyakit inflamasi saluran cerna kronik diketahui berperan penting dalam karsinogenesis KKR.Karsinoma kolorektal diduga berkembang melalui 3 jalur utama yaitu instabilitas kromosom (chromosomal instability), instabilitas mikrosatelit (microsatellite instability) dan $\mathrm{CpG}$ island methylator phenotype (CIMP). ${ }^{6,7}$

Instabilitas mikrosatelit ditandai dengan adanya delesi atau insersi pada sejumlah unit nukleotida berulang dalam DNA.Jalur instabilitas mikrosatelit terdeteksi hanya pada $12-15 \%$ kasus KKR. Instabilitas mikrosatelit disebabkan karena defek pada satu atau lebih gen mismatch repair (MMR). Salah satu gen MMR adalah MLH-1 yang menyandi protein MLH-1. Permasalahan pada mayoritas kasus dengan instabilitas mikrosatelit ini terletak pada gen MLH-1 ini. $^{7,8}$ Gangguan pada gen MMR tersebut menyebabkan hilangnya ekspresi protein MMR sehingga protein tidak menjalankan fungsinya. Perubahan yang terjadi di tingkat gen akan menyebabkan perubahan fenotip yang seringkali terkait dengan parameter klinikopatologik, seperti usia, jenis kelamin, lokasi tumor dan subtipe histopatologik. ${ }^{1}$

Gambaran klinikopatologik dan penanda biologik seringkali digunakan sebagai faktor prognostik ataupun faktor prediktif. Faktor prognostik adalah faktor yang dapat memprediksi agresivitas penyakit, sedangkan faktor prediktif adalah faktor yang dapat memprediksi hasil pengobatan sehingga akan membantu regimen pengobatan. Oleh karena itu, tingkat keberhasilan terapi pasien KKR sangat dipengaruhi oleh gambaran klinikopatologik pasien dan penanda biologik.Subtipe histopatologik adalah salah satu faktor prediksi sekaligus faktor prognostik yang paling sering digunakan. Gambaran klinikopatologik yang disertai dengan hasil 
pemeriksaan instabilitas mikrosatelit, yang ditunjukkan dengan ekspresi negatif $\mathrm{MLH}-1$, akan meningkatkan ketepatan terapi sebab sangat mungkin terjadi bahwa pada dua pasien KKR dengan lokasi dan subtipe histopatologik yang sama akan diperoleh hasil pengobatan yang berbeda jika hanya menggunakan subtipe histopatologik. ${ }^{9}$ Secara klinik, saat ini tatalaksana pasien KKR berdasarkan pada stadium tumor. Pada pasien KKR stadium II, pemberian kemoterapi adjuvan masih dipertimbangkan dan belum menjadi standar pengobatan. Pemeriksaan instabilitas mikrosatelit dapat digunakan untuk membantu menentukan perlu atau tidaknya pemberian kemoterapi adjuvan. ${ }^{10}$

Saat ini, banyak penelitian telah membuktikan akan pentingnya pemeriksaan status instabilitas mikrosatelit untuk semua individu yang didiagnosis sebagai KKR, terutama pasien KKR stadium II dan III. Sebuah penelitian tentang ekspresi negatif mismatch repair (MMR) gene dan microsatellite instability (MSI) di FK USU Medan, lalu menghubungkannya dengan usia, jenis kelamin dan lokasi tumor pada pasien KKR didapatkan hasil KKR MSI-H lebih tinggi pada perempuan $(p=0,18)$ dan pasien berusia $\geq 50$ tahun $(p$ $=0,88)$. Analisis multivariat menunjukkan bahwa KKR dengan ekspresi negatif MLH-1 berhubungan dengan lokasi tumor di proksimal $(p=0,006) .{ }^{11}$ Penelitian lain menunjukkan hasil ekspresi negatif MLH-1 pada KKR paling banyak diklasifikasikan sebagai adenokarsinoma medullari, adenokarsinoma dengan komponen musinosa $<50 \%$, adenokarsinoma musinosa dan adenokarsinoma konvensional $(p=$ $0,001) .^{13}$

Penelitian mengenai hubungan antara ekspresi negatif $\mathrm{MLH}-1$ dengan gambaran klinikopatologik pasien KKR belum pernah dilakukan di Sumatera Barat.Penelitian ini diharapkan dapat memberikan gambaran profil instabilitas mikrosatelit pada pasien KKR di Sumatera Barat.

\section{METODE}

Penelitian ini adalah studi observasional dengan pendekatan cross sectional. Populasi dan sampel adalah kasus karsinoma kolon dan rektum yang diperoleh melalui operasi dan didiagnosis di
SDPA FK Unand Padang, RSUP Dr. M. Djamil Padang, RSI Ibnu Sina Padang dan RSU Achmad Mochtar Bukittinggi periode Juli 2016 - Juni 2017 dan memenuhi kriteria inklusi dan eksklusi. Berdasarkan kriteria inklusi dan eksklusi di dapatkan 81 sampel dan semuanya dilakukan pemeriksaan imunohistokimia $\mathrm{MLH}-1$.

Penelitian dilakukan di Laboratorium Patologi Anatomik Fakultas Kedokteran Universitas Andalas, RS M. Djamil Padang, RSI Ibnu Sina Padang dan RS Achmad Mochtar Bukittinggi. Pada tempat-tempat tersebut dilakukan pengumpulan data kasus Karsinoma Kolorektal yang telah didiagnosis periode Juli 2016-Juni 2017 berupa slaid HE dan blok parafin. Pemeriksaan ulang mikroskopik slaid dan analisis data serta pewarnaan imunohistokimia MLH-1 dilakukan di Laboratorium Patologi Anatomik Fakultas Kedokteran Universitas Andalas.Metode yang digunakan dalam pewarnaan imunohistokimia $\mathrm{MLH}-1$ adalah dengan menggunakan metode Streptavidin Biotin Complex $(S B C)$. Ekspresi dari hasil pewarnaan ini dinilai berdasarkan $\mathrm{H}$-score, yaitu $\mathrm{H}$ score $>55$ dianggap sebagai $\mathrm{MLH}-1$ positif dan $\mathrm{H}$-score $<55$ dianggap sebagai MLH-1 negatif. Faktor klinikopatologik yang dimasukkan pada penelitian ini adalah usia, jenis kelamin, lokasi tumor dan subtipe histopatologik. Analisis statistik bivariat yang digunakan untuk mencari hubungan antara ekpsresi negatif $\mathrm{MLH}-1$ dengan faktor klinikopatologik tersebut adalah uji Chi square, t-test dan one way Annova.

\section{HASIL}

Berdasarkan data sekunder yang diperoleh dari laboratorium Sentra Diagnostik Patologi Anatomik Fakultas Kedokteran Universitas Andalas, RSUP Dr. M. Djamil Padang, RSI Ibnu Sina Padang dan RSU Ahmad Mochtar Bukittinggi periode Juli 2016 sampai Juni 2017, didapatkan populasi sebanyak 83 kasus KKR. Tiga puluh tiga sampel dieksklusi oleh karena blok paraffin rusak (2 buah) dan kualitas pewarnaan imunohistokimia yang tidak memuaskan (31 buah) sehingga sampel penelitian yang memenuhi kriteria inklusi dan eksklusi berjumlah 50 kasus. Penilaian hasil penelitian dan review slaid dilakukan oleh penulis dan didampingi oleh ahli patologi. 
Tabel 1. Karakteristik umum dan subtipe histopatologik KKR

\begin{tabular}{|c|c|c|}
\hline Karakteristik & $F(n=50)$ & $\%$ \\
\hline \multicolumn{3}{|l|}{ Umur (tahun) } \\
\hline$\leq 40$ tahun & 10 & $20 \%$ \\
\hline$>40$ tahun & 40 & $80 \%$ \\
\hline \multicolumn{3}{|l|}{ Jenis kelamin } \\
\hline Laki-laki & 23 & $46 \%$ \\
\hline Perempuan & 27 & $54 \%$ \\
\hline \multicolumn{3}{|l|}{ Lokasi } \\
\hline Kolon proksimal & 17 & $34 \%$ \\
\hline Kolon distal & 10 & $20 \%$ \\
\hline Rektum & 23 & $46 \%$ \\
\hline \multicolumn{3}{|l|}{ Subtipe histopatologik } \\
\hline Adenokarsinoma lain & 33 & $66 \%$ \\
\hline Mucinous carcinoma & 17 & $34 \%$ \\
\hline
\end{tabular}

Tabel 1 menunjukkan karakteristik umum dan subtipe histopatologik KKR.Sebagian besar penderita KKR berusia $>40$ tahun yaitu 40 orang (80\%).Jumlah penderita KKR terbanyak adalah pada jenis kelamin perempuan adalah 27 orang (54\%). Karsinoma paling banyak berlokasi di rektum yaitu berjumlah 23 kasus (46\%). Subtipe histopatologik terbanyak adalah adenokarsinoma lainnya yaitu berjumlah 33 orang (66 $\%)$.

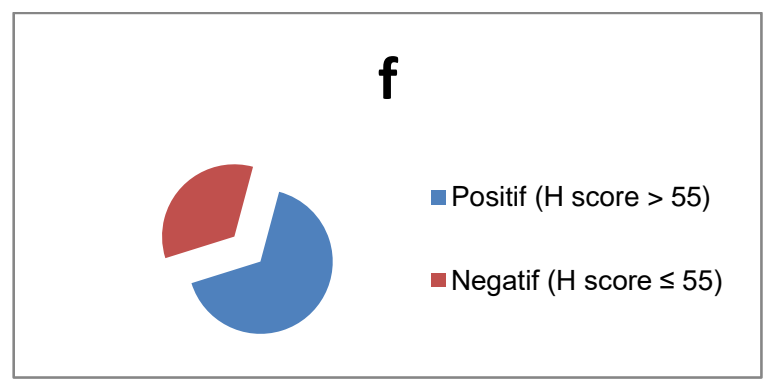

Gambar 1. Ekspresi MLH-1 pada pasien KKR di Sumatera Barat

Gambar 1 menunjukkan ekspresi MLH-1 pada pasien KKR di 4 Laboratorium Patologi Anatomik di Sumatera Barat. Ekspresi MLH-1 ini dinilai berdasarkan $H$-score, yaitu nilai $H$-score $>55$ dianggap MLH-1 positif dan ditemukan pada 33 kasus (66\%) sedangkan nilai $\mathrm{H}$-score $\leq 55$ dianggap sebagai $\mathrm{MLH}-1$ negatif dan ditemukan pada 17 kasus (34\%). Pada penelitian ini, nilai $\mathrm{H}$-score terendah adalah 0 dan nilai $\mathrm{H}$-score tertinggi adalah 250 (Gambar 2).

A.

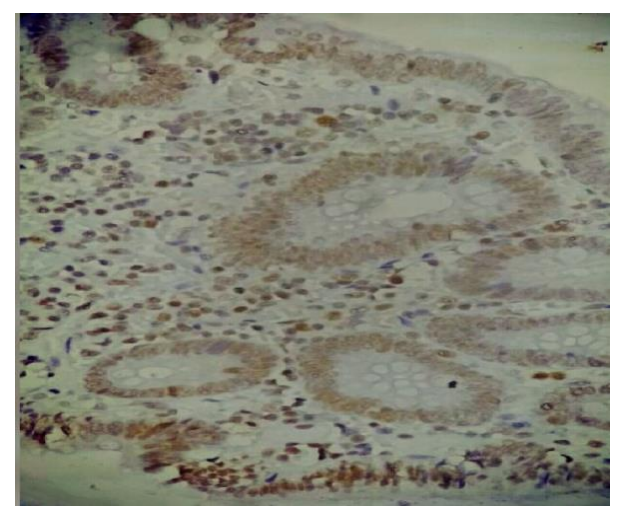

B.

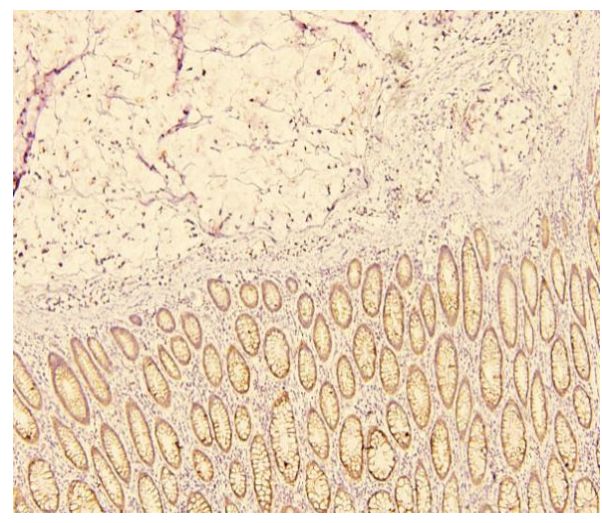

Gambar 2. Ekspresi MLH-1 A.Ekspresi MLH-1 positif pada inti kripti normal sebagai kontrol positif internal (40xobj) B. Ekspresi MLH-1 negatif $(H$-score $\leq 55)$

Sebelum dilakukan uji statistik, terlebih dahulu dilakukan uji normalitas data dengan KolmogorovSmirnov dan didapatkan data terdistribusi normal. Oleh karena itu dilakukan parametric test (Chi square test). Hubungan ekspresi MLH-1 berdasarkan skala ukur positif dan negatifdengan karakteristik umum KKR dapat dilihat pada Tabel 2.

Tabel 2 memperlihatkan perbedaan ekspresi MLH-1 berdasarkan skala ukur positif dan negatif pada kelompok usia, jenis kelamin, lokasi tumor dan subtipe histopatologik. Ekspresi MLH-1 negatif pada penelitian ini lebih banyak ditemukan pada kelompok $>40$ tahun sebanyak 12 kasus (70,6\%), pada pasien dengan jenis kelamin laki-laki sebanyak 9 kasus (52,9\%), pada pasien dengan karsinoma kolon proksimal sebanyak 9 kasus $(52,9 \%)$ dan pada pasien KKR dengan subtipe histopatologik adenokarsinoma musinosa sebanyak 11 
kasus $(64,7 \%)$. Secara statistik perbedaan ekspresi negatif $\mathrm{MLH}-1$ pada kelompok usia, jenis kelamin dan lokasi tumor menunjukkan hubungan yang tidak bermakna dengan masing-masing nilai $p$ secara berurutan adalah 0,277, 0,557 dan 0,093 ( $p>0,05$ ). Sedangkan perbedaan ekspresi negatif $\mathrm{MLH}-1$ pada subtipe histopatologik secara statistik menunjukkan hubungan yang bermaknadengan nilai $p$ adalah 0,002 $(p<0,05)$.

Tabel 2. Hubungan karakteristik umum dengan skala ukur positif dan negatif ekspresi MLH-1

\begin{tabular}{|c|c|c|c|c|c|}
\hline & & Ekspres & MLH- & & \\
\hline & + & & - & & $\mathrm{p}$ \\
\hline & $f$ & $\%$ & $f$ & $\%$ & \\
\hline Usia & & & & & \\
\hline$\leq 40$ & 5 & $15,2 \%$ & 5 & $29,4 \%$ & 0,277 \\
\hline$>40$ & 28 & $84,8 \%$ & 12 & $70,6 \%$ & \\
\hline JK & & & & & \\
\hline$\widehat{\sigma}$ & 14 & $42,4 \%$ & 9 & $52,9 \%$ & 0,55 \\
\hline 우 & 19 & $57,6 \%$ & 8 & $47,1 \%$ & 7 \\
\hline Lokasi & & & & & \\
\hline Proks & 8 & $24,2 \%$ & 9 & $52,9 \%$ & \\
\hline Dist & 8 & $24,2 \%$ & 2 & $11,8 \%$ & 0,09 \\
\hline Rekt & 17 & $51,5 \%$ & 6 & $35,3 \%$ & 3 \\
\hline Subtipe & & & & & \\
\hline Adeno & 27 & $81,8 \%$ & 6 & $35,3 \%$ & \\
\hline Musin & 6 & $18,2 \%$ & 11 & $64,7 \%$ & 0,00 \\
\hline & & & & & 2 \\
\hline
\end{tabular}

Tabel 3 memperlihatkan perbedaan ekspresi MLH-1 pada masing-masing kelompok usia, jenis kelamin, lokasi tumor dan subtipe histopatologik. Ekspresi $\mathrm{MLH}-1$ dengan nilai lebih rendah terdapat pada kelompok usia $>40$ tahun, jenis kelamin perempuan, lokasi tumor di proksimal dan subtipe histopatologik karsinoma musinosa. Secara statistik perbedaan ekspresi MLH-1 pada kelompok usia, jenis kelamin dan lokasi tumor menunjukkan hubungan yang tidak bermakna dengan masing-masing nilai $p$ secara berurutan adalah 0,579, 0,979 dan 0,179 ( $p>0,05)$. Sedangkan perbedaan ekspresi MLH-1pada subtipe histopatologik secara statistik menunjukkan hubungan yang bermakna dengan nilai $p$ adalah 0,001 $(p<0,05)$.
Tabel 3. Hubungan ekspresi MLH-1 dengan kelompok usia, jenis kelamin, lokasi tumor dan subtipe histopatologi KKR

\begin{tabular}{|c|c|c|}
\hline \multicolumn{3}{|c|}{ Nilai persentase } \\
\hline & $\mathrm{X}+\mathrm{SD}$ & $\mathbf{p}$ \\
\hline \multicolumn{3}{|l|}{ Usia } \\
\hline$\leq 40$ & $87,50 \pm 98,072$ & 0,579 \\
\hline$>40$ & $103,00 \pm 73,186$ & \\
\hline \multicolumn{3}{|l|}{ JK } \\
\hline$\hat{0}$ & $100,22 \pm 80,347$ & 0,979 \\
\hline 우 & $99,63 \pm 77,297$ & \\
\hline \multicolumn{3}{|l|}{ Lokasi } \\
\hline Proksimal & $73,24 \pm 75,207$ & \\
\hline Distal & $100,00 \pm 64,464$ & 0,179 \\
\hline Rektum & $119,57 \pm 77,903$ & \\
\hline \multicolumn{3}{|l|}{ Subtipe } \\
\hline Adeno & $125,45 \pm 69,680$ & 0,001 \\
\hline Musinosa & $50,29 \pm 70,100$ & \\
\hline
\end{tabular}

\section{PEMBAHASAN}

\section{Karakteristik umum dan subtipe histopatologik KKR}

Penelitian ini menyatakan bahwa jumlah penderita KKR usia $>40$ tahun lebih tinggi dibandingkan dengan usia $\leq 40$ tahun yaitu 40 orang (80\%) berusia $>40$ tahun dan 10 orang $(20 \%)$ berusia $\leq 40$ tahun. Penelitian lain di Fakultas Kedokteran Unpad Rumah Sakit Hasan Sadikin Bandung yang mendapatkan angka kejadian KKR pada usia $\leq 40$ tahun lebih tinggi dibandingkan dengan usia $>40$ tahun, yaitu dari 39 orang penderita KKR, 22 orang $(56,4 \%)$ berusia $\leq 40$ tahun dan 17 orang $(43,6 \%)$ berusia $>40$ tahun. Tingginya kasus KKR pada usia $\leq$ 40 tahun pada penelitian tsb membuktikan tingginya kasus KKR usia $\leq 40$ tahun di Jawa Barat, yaitu berkisar antara $15 \%$ sampai $54 \% .^{12}$

Usia rata-rata penderita KKR pada penelitian ini adalah 55,02 tahun, hampir sama dengan penelitian lain dimana usia rata-rata KKR di negara sedang berkembang adalah 50 tahun, hanya sekitar $9 \%$ kasus terjadi sebelum usia 50 tahun dan sekitar $1 \%$ terjadi sebelum usia 35 tahun. ${ }^{6}$ Usia penderita KKR penting untuk diketahui, karena hal ini berkaitan dengan perilaku penyakit dan penyakit genetik pada KKR. 
Pasien KKR usia muda dianggap memiliki prilaku biologik lebih agresif dan prognosis lebih buruk dibandingkan dengan usia tua. ${ }^{14}$ Jika ditemukan keganasan kolorektal pada usia muda, maka hal ini meningkatkan kecurigaan terhadap adanya inherited cancer syndrome. ${ }^{15}$

Pada penelitian ini, $80 \%$ kasus KKR terjadi pada usia $>40$ tahun. Sebagian besar karsinoma terjadi pada tahun-tahun akhir kehidupan (>55 tahun). Peningkatan insiden karsinoma sesuai dengan peningkatan usia dapat dijelaskan sebagai akumulasi mutasi somatik yang berhubungan dengan terjadinya neoplasma malignan. Penurunan kemampuan sistem imun yang mengiringi proses penuaan juga menjadi faktor pemberat serta masih kurangnya kesadaran sebagian besar pasien berusia $>50$ tahun untuk melakukan uji skrining terutama di negara berkembang. ${ }^{8}$

Pada penelitian ini, frekuensi penderita KKR berjenis kelamin perempuan lebih banyak dibandingkan dengan penderita laki-laki, yaitu sebanyak 27 orang (54\%) berjenis kelamin perempuan dan 23 orang (46\%) berjenis kelamin laki-laki. Di RS Hasan Sadikin Bandung menunjukkan hasil yang agak berbeda, frekuensi penderita KKR berjenis kelamin laki-laki lebih banyak dibandingkan dengan penderita perempuan, yaitu sebanyak 21 kasus (54\%) penderita KKR adalah laki-laki, 18 kasus (46\%) penderita KKR adalah perempuan, dengan perbandingan laki-laki: perempuan adalah 1,17: $1 .^{12} \mathrm{Hal}$ ini sesuai dengan data dari Global Cancer Statistic tentang kejadian KKR berdasarkan jenis kelamin dimana laki-laki agak lebih banyak dari pada perempuan dengan perbandingan 19,4 dan 15,3 per 100.000 penduduk. ${ }^{15}$ Karsinoma kolorektal dapat terjadi baik pada laki-laki maupun perempuan, variasi rasio jenis kelamin dalam beberapa penelitian disebabkan karena adanya perbedaan perilaku antar jenis kelamin dalam suatu populasi berkaitan dengan kebiasaan makan, merokok, konsumsi alkohol dan latihan fisik. ${ }^{15}$ Merupakan suatu hal yang penting untuk mengetahui jenis kelamin pada penderita KKR dalam suatu populasi, karena jenis kelamin laki-laki berhubungan dengan insidens KKR yang lebih tinggi dan prognosis lebih buruk. Alasan dari hubungan ini tidak dapat dijelaskan dengan baik, tetapi mungkin berhubungan dengan perbedaan stadium tumor dan paparan estrogen. Karsinoma kolorektal pada perempuan sering muncul di usia lanjut, stadium penyakit lebih rendah dan cenderung untuk menjalani reseksi bedah kuratif. Lebih jauh, studi yang ada saat ini menduga bahwa dibandingkan dengan laki-laki, perempuan dengan KKR memiliki kelangsungan hidup jangka pajang lebih baik. ${ }^{17}$ Sejumlah studi observasi menyatakan bahwa peningkatan kadar hormon perempuan pada kehamilan dan penggunaan hormon eksogen seperti kontrasepsi oral serta terapi hormonal post menopausal berhubungan dengan risiko lebih rendah berkembangnya KKR pada perempuan. ${ }^{18}$

Pada penelitian ini, jumlah karsinoma kolon proksimal lebih banyak dari pada kolon distal, yaitu sebanyak 17 kasus (34\%) karsinoma kolon proksimal, 10 kasus (20\%) karsinoma kolon distal. Hal ini penting diketahui karena karsinoma kolon proksimal memiliki kecenderungan untuk muncul dalam stadium lebih lanjut serta memiliki prognosis yang lebih buruk dibandingkan dengan karsinoma kolon distal. ${ }^{19,20}$ Beberapa penelitian belakangan ini menyimpulkan bahwa insidens karsinoma kolon proksimal meningkat dibandingkan dengan karsinoma kolon distal. Hal ini dapat disebabkan oleh karena, saat ini beberapa populasi telah memiliki akses layanan kolonoskopi yang lebih baik sehingga karsinoma kolon proksimal lebih mudah dijangkau melalui kolonoskopi. Pada penelitian ini, tingginya insidens karsinoma kolon proksimal lebih dikaitkan dengan profil biologik yang berbeda pada populasi ini. ${ }^{15}$

Karsinoma musinosa berjumlah sekitar 10\% dari seluruh $\mathrm{KKR} .{ }^{15} \mathrm{Hal}$ ini penting diketahui, karena karsinoma musinosa memiliki prognosis yang lebih buruk dibandingkan dengan adenokarsinoma tanpa komponen musinosa.

\section{Ekspresi MLH-1 pada pasien KKR}

Ekspresi MLH-1 positif ditemukan pada 33 kasus (66\%) sedangkan ekspresi MLH-1 negatif pada 17 kasus (34\%). Ekspresi MLH-1 negatif lebih rendah pada penelitian ini dibandingkan dengan penelitian di Jakarta, Bandung dan Makasar, yang mendapatkan jumlah kasus KKR yang memiliki ekspresi $\mathrm{MLH}-1$ negatif adalah 81 kasus (83,5\%), sedangkan yang menunjukkan ekspresi MLH-1 positif pada inti adalah 
16 kasus (16,5\%). ${ }^{18}$ Tingginya pewarnaan negatif pada penelitiannya ini disebabkan karena 2 hal, yaitu ketiadaan ekspresi protein $\mathrm{MLH}-1$ akibat defek gen MMR atau karena kegagalan reagen dan kesalahan teknik prosedur pewarnaan. Untuk evaluasi skrining kasus instabilitas mikrosatelit sesungguhnya para ahli masih membutuhkan pewarnaan tambahan, yaitu MSH2, MSH6 dan PMS2 meskipun pewarnaan imunohistokimia MLH-1 untuk instabilitas mikrosatelit ini cukup sensitif.Untuk menentukan status instabilitas mikrosatelit kasus KKR, dibutuhkan panel imunohistokimia. Antibodi yang dipilih adalah $\mathrm{MLH}-1$ dan MSH-2, karena MLH-1 dimerisasi dengan PMS2 dan $\mathrm{MSH}-2$ dimerisasi dengan $\mathrm{MSH}-6{ }^{21}$

Penelitian ini mendekati hasil penelitian lain di Medan yang mendapatkan ekspresi $\mathrm{MLH}-1$ positif terdapat pada 49 kasus $(63,6 \%)$ dan ekspresi MLH-1 negatif pada 28 kasus $(36,4 \%) .{ }^{11}$ Penelitian di Turki pada 186 kasus KKR, didapatkansebanyak 16 orang (8,6\%) menghasilkan ekspresi pewarnaan MLH-1 $<1 \%, 52$ kasus (28\%) menghasilkan ekspresi pewarnaan $\mathrm{MLH}-1$ 1-50\%, sisanya sebanyak 118 kasus $(63,4 \%)$ menghasilkan ekspresi pewarnaan $\mathrm{MLH}-1>50 \%{ }^{7}$

Hasil ekspresi negatif MLH-1 pada penelitian ini lebih tinggi dibandingkan dengan pendapat lain yang menyatakan bahwa defisiensi pada gen perbaikan ketidakcocokan DNA yang menghasilkan instabilitas mikrosatelit di Amerika Serikatditemukan pada sekitar $15 \%$ kasus KKR, sedangkan di Korea Selatan dan Taiwan ditemukan $<10 \%$ kasus. $^{22}$ Perbedaan hasil penelitian ini dapat disebabkan karena memang tingginya frekuensi KKR melalui jalur instabilitas mikrosatelit di Sumatera Barat. Instabilitas mikrosatelit disebabkan karena defek pada satu atau lebih gen mismatch repair (MMR). Secara imunohistokimia, defisiensi gen MMR dapat diketahui melalui ketiadaan ekspresi MLH-1, karena masalah utama kasus instabilitas mikrosatelit baik sporadik maupun inherited terletak pada gen $\mathrm{MLH}-1 .{ }^{21}$ Pemeriksaan instabilitas mikrosatelit dapat digunakan untuk membantu menentukan perlu atau tidaknya pemberian kemoterapi adjuvan (5-Fluorouracil/ 5-FU) terutama pada pasien KKR stadium II. ${ }^{10}$

\section{Hubungan ekspresi MLH-1 dengan karakterisik umum KKR}

Ekspresi negatif MLH-1 lebih banyak ditemukan pada pasien berusia $>40$ tahun dibandingkan dengan usia $\leq 40$ tahun, yaitu $70,6 \%$ pada pasien berusia $>40$ tahun dan $29,4 \%$ pada pasien berusia $\leq 40$ tahun, meskipun secara statistik tidak terdapat hubungan bermakna antara ekspresi negatif $\mathrm{MLH}-1$ dengan usia dengan nilai $p=0,277 \quad(0>0,05)$. Penelitian lain menunjukkan dari 9 kasus KKR dengan MSI, 5 orang diantaranya berusia $\leq 40$ tahun dan 4 orang lainnya berusia $>40$ tahun. Hasil uji statistik ekspresi negatif MLH-1 pada penelitian tsb menyimpulkan tidak terdapat perbedaan bermakna antara kedua kelompok tersebut, dengan nilai $p=0,623 .{ }^{13}$ Terdapat perbedaan bermakna antara status MSI dengan usia, dengan nilai $p<0,01$. Khan menunjukkan hasil lebih banyak ditemukan kasus KKR MSI pada usia muda ( $\leq 30$ tahun) dibandingkan dengan usia lanjut ( $\geq 50$ tahun). Penelitian ini agak berbeda, disebabkan karena tingginya insidens mutasi MMR yang menyebabkan kanker genetik pada populasi tersebut. Instabilitas mikrosatelit pada pasien usia muda ini tidak muncul bersamaan dengan mutasi $\operatorname{BRAF}^{\mathrm{V} 600 \mathrm{E}} \quad(p<0,01)$ sehingga diduga kejadian ini lebih sering muncul pada sindrom Lynch. ${ }^{23}$ Pada penelitian ini, dari 17 kasus MLH-1 negatif belum dapat dibedakan apakah ini merupakan kasus sporadik atau Lynch syndrome, karena berdasarkan algoritma uji skrining universal defek DNA mismatch repair (gambar 6.1), untuk mengelompokkan KKR MLH-1 deficient kedalam kelompok sporadik, membutuhkan uji tambahan, yaitu uji BRAF. ${ }^{6}$

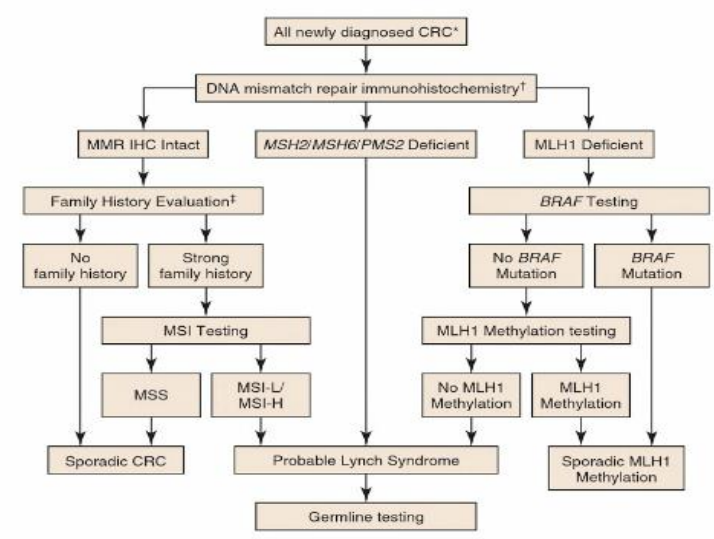

Gambar 3. Algoritma uji skrining universal terhadap defek DNA mismatch repair. ${ }^{6}$ 
Pada penelitian ini, ekspresi negatif $\mathrm{MLH}-1$ lebih banyak ditemukan pada laki-laki dibandingkan perempuan, yaitu sebanyak $52,9 \%$ pada laki-laki dan $47,1 \%$ pada perempuan, meskipun hasil uji statistik hubungan ekspresi negatif $\mathrm{MLH}-1$ pada pasien KKR terhadap jenis kelamin tidak bermakna dengan nilai $p=0,557(p>0,05)$. Penelitian lain menunjukkan hasil sebanyak 13 orang $(44,8 \%)$ kasus $\mathrm{MSI}-\mathrm{H}$ merupakan laki-laki, dan sebanyak 16 orang $(55,2 \%)$ kasus $\mathrm{MSI}-\mathrm{H}$ merupakan perempuan. ${ }^{11}$ Terdapat hubungan tidak bermakna antara status $\mathrm{MSI}-\mathrm{H}$ dengan jenis kelamin pasien $K K R$, dengan nilai $p=0,18$. Kemampuan perbaikan ketidakcocokan DNA dan stabilitas mikrosatelit diperkuat oleh estrogen melalui induksi ekspresi MLH-1.Efek inhibisi terhadap proliferasi sel tumor baik secara in vitro maupun in vivo, yang dikombinasikan dengan 5-FU melalui up-regulation ekspresi MLH-1.Oleh karena itu estrogen diduga merupakan efek protektif terhadap KKR jalur instabilitas mikrosatelit. Beberapa studi menunjukkan perempuan kurang mudah terkena KKR jalur instabilitas mikrosatelit dibandingkan laki-laki dalam kelompok usia yang sama. ${ }^{24}$

Ekspresi negatif MLH-1 lebih banyak ditemukan pada kolon proksimal dibandingkan distal, yaitu 52,9\% berada di kolon proksimal, $11,8 \%$ berada di kolon distal dan 35,3\% berada di rektum, meskipun hasil uji statistik hubungan ekspresi negatif $\mathrm{MLH}-1$ dengan lokasi tidak bermakna dengan nilai $p=0,093$ ( $p>0,05$ ). Penelitian ini mendukung penelitian lain yang menyatakan dari 28 kasus KKR dengan MLH-1 negatif, 9 kasus $(37,5 \%)$ berada di kolon proksimal, 4 kasus $(16,7 \%)$ berada di kolon distal dan 15 kasus $(51,7 \%)$ berada di rektum. ${ }^{11}$ Lebih tingginya insidens KKR MSI, yang mengalami mutasi BRAF dan fenotipe CIMP berhubungan dengan perbedaan biologik antara kolon proksimal dan distal yang secara potensial bermakna dalam terjadinya tumorigenesis. Sedikit sekali pengetahuan yang dapat menjelaskan tentang heterogenitas tumor ini.Suatu perbedaan nyata dapat dijelaskan karena asal embrionik dari kolon proksimal dan distal berbeda. Secara embriologi, saekum, appendiks, kolon asenden dan 2/3 proksimal kolon transversum berasal dari midgut, sedangkan 1/3 distal kolon transversum, kolon desenden, kolon sigmoid dan rektum berasal dari hindgut. Jalur yang terlibat dalam perkembangan KKR di kedua segmen ini sampai sekarang masih diteliti secara luas dan pada akhirnya disepakati bahwa profil biologik dari masingmasing kanker memegang peranan penting. Sebagai tambahannya, perbedaan konten lumen dan flora bakteri antara kolon proksimal dan kolon distal juga mempengaruhi onkogenesis. ${ }^{22}$

Ekspresi negatif MLH-1 lebih banyak ditemukan pada karsinoma musinosa dibandingkan adenokarsinoma lain, yaitu $64,7 \%$ adalah karsinoma musinosa dan $35,3 \%$ adalah adenokarsinoma lainnya. Hasil uji statistik menyimpulkan terdapat hubungan bermakna antara ekspresi $\mathrm{MLH}-1$ dengan subtipe histopatologik KKR dengan nilai $p=0,002 \quad(p<0,05)$. Hasil ini mendukung penelitian Karahan yang menyatakan bahwa hilangnya ekspresi negatif MLH-1 berhubungan dengan histopatologik musinous adeno carcinoma $(p<0,0001) .^{7}$ Sebuah studi menyatakan bahwa tidak hanya adenokarsinoma musinosa tetapi tumor dengan komponen musinous <50\% juga berhubungan dengan $\mathrm{MSI}^{23}$ Subtipe histopatologik adenokarsinoma musinosa menunjukkan gambaran patologik yang lebih agresif dibandingkan dengan adenokarsinoma lainnya, karena respon yang terbatas terhadap terapi sistemik, terutama pada tumor yang sudah bermetastasis serta kecenderungannya untuk menyebar ke peritoneum yang lebih nyata, meskipun mekanismenya masih belum jelas. Sedangkan KKR MSI yang sebagian besar terdiri dari tipe histologik agresif ini menunjukkan prognosis yang lebih baik dibandingkan dengan KKR MSS. ${ }^{24}$ Oleh karena itu, terjawab sudahlah kontroversi prognosis pada adenokarsinoma musinosa yang ada selama ini, bahwa sebagian adenokarsinoma musinosa ternyata memiliki prognosis lebih baik, karena memang sebagian dari adenokarsinoma musinosa tersebut mengalami jalur karsinogenesis instabilitas mikrosatelit.

Kelemahan penelitian ini adalah adanya perbedaan dalam hal prosedur pewarnaan imunohistokimia. 


\section{SIMPULAN}

Ekspresi MLH-1 positif lebih banyak ditemukan dibandingkan dengan ekspresi $\mathrm{MLH}-1$ negatif, jadi instabilitas mikrosatelit tidak merupakan jalur karsinogenesis yang lebih dominan untuk kasus KKR yang didiagnosis di laboratorium PA di Sumatera Barat. Ekspresi MLH-1 negatif justru ditemukan lebih banyak pada subtipe adenokarsinoma musinosum, hal ini berkaitan dengan kontroversi pada prognosis adenokarsinoma musinosum yang pada awanya diketahui memiliki perilaku biologik dan prognosis yang buruk, ternyata sebagian adenokarsinoma musinosum memiliki perilaku biologik dan prognosis yang lebih baik

\section{DAFTAR PUSTAKA}

1. Yantiss RK. Morphologic classification of colorectal epithelial tumors. Dalam: Cagle PT, Allen TC, editor (penyunting). Advances in surgical pathology colorectal carcinoma and tumors of the vermiform appendix. Philadelphia: Lippincott William and Wilkins. 2014.hlm.101-10.

2. Siegel RL, Miller KD, Fedewa SA, Ahnen DJ, Meester RGS, Barzi A, et al. Colorectal cancer statistics, published June 2017. Ca Cancer J Clin 2017;67(3):177-93.

3. Pande M, Frazier ML. Epidemiology. Dalam: Scholefield JH, Eng C, editor (penyunting). Colorectal cancer, diagnosis and clinical management. Edisi ke-1. New York: John Wiley and Sons Blackwell. 2014.hlm. 3-10.

4. Hamdi M, Zahari A, Aswiyanti. Profil karsinoma kolorektal di laboratorium patologi anatomi fakultas kedokteran Universitas Andalas periode Januari 2009 sampai Desember 2011. Jurnal Kesehatan Andalas. 2015;4(2):398-402.

5. Dehkordi B, Safaee A. An overview of colorectal cancer survival rates and prognosis in Asia. World J Gastrointest Oncol. 2012;15(5):71-5.

6. Redston M, Driman DK. Epithelial neoplasm of the large intestine. Dalam: Odze RD, Goldblum JR, editor (penyunting). Odze and Goldblum surgical pathology of $\mathrm{Gl}$ tract, liver, billiary tract and pancreas. Edisi ke-3. Philadelphia: Elsevier saunders. 2015.hlm.737-48.
7. Karahan B, Argon A, Yildirim M, Vardar E. Relationship between MLH-1, MSH-2, PMS-2, MSH-6 expression and clinicopathological features in colorectal cancer. Int $\mathrm{J}$ Clin Exp Pathol. 2015;8(4):4044-53.

8. Kumar V, Robbins, Leonard S. Neoplasia. Dalam: Kumar V, Abbas AK, Fausto N, Aster JC, editor (penyunting). Robbins and Cotran Pathologic Basis of Disease. Edisi ke-8. Philadelphia: Saunders Elsevier; 2010.hlm.234-69.

9. Marzouk O, Schofield J. Review of histopathological and molecular prognosis features in colorectal cancer. Cancer (based). June 23 $2011 ; 3(2): 2767-810$.

10. Gatalica Z, Vranic S, Xiu J, Swensen J, Reddy S. High microsatellite instability $(\mathrm{MSI}-\mathrm{H})$ colorectal carcinoma: a brief review of predictive biomarkers in the era of personalized medicine. Familial Cancer. 2016;15(6):405-12.

11. Effendi R-YS, Zain LH, Siregar GA, Lubis HR, Damanik HA, Laksmi LI, et al. Adenomatous polyposis coli, mismatch repair and microsatellite instability in colorectal cancer based on different locations. Acta Med Indonesia-Indones J Intern Med. 2013;45(4):275-82.

12. Lukman K, Yuniasari L, Hernowo BS. Hubungan faktor risiko, status instabilitas mikrosatelit dan ekspresi P53 dengan karsinogenesis adenokarsinoma kolorektal pada orang Indonesia. MKB. 2012;44( 4): 245-50.

13. Campos FG. Colorectal cancerin young adults. Worlds J Gastroenterol. 2017; 23 (28): 5041-4.

14. Walsh SV, Carey FA. Malignant epithelial neoplasms of the large bowel. Dalam: Shepherd NA, Warren BF, Williams GT, Greenson JK, Lauwers GY, Novelli MR, editor (penyunting). Morsons and Dowson's Gastrointestinal Pathology. Edisi ke-5. United Kingdom: John Wiley and Sons 2014. hlm. 691-703.

15. Jemal A, Bray F, Center MM, Ferlay J, Ward E, Forman D. Global cancer statistics. Cancer J Clin. 2011;61(2):69-90.

16. Quirt JD, Nanji S, Wei X, Flemming JA and Booth CM. Is There a sex effect in colon cancer? disease characteristics, management and outcomes in 
routine clinical practice. Curr Oncol. 2017;24(1): 15-23.

17. Lin JH, Zhang SM, Rexrode KM, Manson JE, Chan $\mathrm{AT}, \mathrm{Wu} \mathrm{K}$, et al. Association between sex hormones and colorectal cancer risk in men and women. Clin Gastroenterol Hepatol. 2013;11(4): 419-24.

18. Sudoyo AW, Hernowo B, Krisnuhoni E, Reksodiputro AH, Hardjodisastro D, Sinuraya ES. Colorectal cancer among young native Indonesians: A clinicopathological and molecular assessment of microsatellite instability. Med $\mathrm{J}$ Indonesia. 2010;19(4):245-51.

19. Maru D. How histopathology affects the management of the multidisciplinary team. Dalam: Scholefield JH, Eng C, editor (penyunting). Colorectal cancer, diagnosis and clinical management. Edisi ke-1. New York: John Wiley and Sons Blackwell; 2014.hlm.80-90.
20. Rosai J. Surgical pathology. Edisi ke-10. New York: Elsevier Saunders; 2011.hlm.731-42.

21. Khan SA, Morris M, Idress K, Gimbel MI, Rosenberg S, Zeng Z, et al. Colorectal cancer in the very young: a comparative study of tumor markers, pathology and survival in early onset and adult patients. J Pediatr Surg. 2016;51:1812-7.

22. Lu JY, Jin P, Gao W, Wang DZ, Sheng JQ. Estrogen enhances mismatch repair by induction of MLH-1 expression via estrogen receptor-B. Oncotarget. 2017;8(24):38767-79.

23. Greenson JK, Huang SC, Herron C, Moreno V, Bonner JD, Tomsho LP, et al. Pathologic predictors of microsatellite instability in colorectal cancer. Am J Surg Patho. 2009;33(25):126-33.

24. Kim HJ. Mucinous subtype in patients with colorectal cancer. Ann Coloproctol. 2014;33(2): 44-5. 